\title{
Screening of chilli genotypes for drought tolerance
}

\author{
R George \& KB Sujatha
}

Journal of Agriculture and Ecology

Volume-8 (December, 2019)

ISSN: 2456-9410

\section{Journal of Agriculture} and Ecology

ISSN: 2456-9410

Volume: 8

Journal of Agriculture and Ecology (2019) 8: 38-45 http://doi.org/10.53911/JAE.2019.8205 


\title{
Screening of chilli genotypes for drought tolerance
}

\author{
R George $\square \&$ KB Sujatha \\ Department of Crop Physiology \\ Tamil Nadu Agricultural University, Coimbatore - 641003 \\ Corresponding author: VCM Anu Udaya, Email: renugeorge93@gmail.com
}

\section{Article Info Abstract}

Article history

Received: 20 September 2018

Accepted: 15 November 2018

Available online: 5 August 2019

Key Words: Capsicum

annuum L., Field

Capacity, Cell

membrane integrity,

Lipid peroxidation.
Chilli (Capsicum annuum L.) is an important solanaceous crop highly susceptible to drought due its higher transpiring leaf surface, high stomatal conductance and low membrane integrity. The pot culture experiment to screen the 12 chilli genotypes for drought tolerance was conducted with two treatments with $100 \%$ field capacity as control and $50 \%$ field capacity as drought and screening was done on the basis of various parameters. The overall results revealed that the tolerant genotypes maintained higher level of cell membrane integrity, chlorophyll stability, osmolyte accumulation and low lipid peroxidation under drought. Among the genotypes, CA 176 showed its supremacy by maintaining higher chlorophyll content, relative water content, cell membrane integrity and lower lipid peroxidation followed by CA 183 in its performance under drought. On the other hand CA 45, CA 104 and CA 174 showed poor performance by being very sensitive to water stress with very low yield.

Copyright (O2019 George \& Sujatha, This is an open access article published under the terms of the Creative Commons Attribution License, which permits unrestricted use, distribution, and reproduction in any medium, provided the original work is properly cited.

Preferred citation: R George \& KB Sujatha. 2019. Screening of chilli genotypes for drought tolerance. Journal of Agriculture and Ecology, 8: 38-45; http://doi.org/10.53911/JAE.2019.8205.

\section{Introduction}

Chilli (Capsicum annuum L.) is an important spice in every Indian Cuisine because of its pungency, spicy taste, appealing colour and flavour. Chillies are very sensitive to various biotic and abiotic stresses. In chillies, the flowering and fruit development stages are very much sensitive to drought situations negatively affect the fruit yield (Antony \& Singandhupe 2004). Drought is an abiotic stress that causes reduction in plant growth and yield and also leads to decline in several physiological and biochemical characters. Water stress leads to the loss of cell turgidity, stomatal closure which in turn affects the leaf gas exchange, increase in foliage temperature and decrease chlorophyll stability index (Sivakumar et al. 2014). Drought causes decline in stomatal conductance, net photosynthesis (Singh \& Raja Reddy 2011) and leaf chlorophyll content (Gladden et al. 2012). Water deficit conditions leads to a decreased $\mathrm{Fv} / \mathrm{Fm}$ ratio due to protein deactivation in chlorophyll 
structure (Hazrati et al. 2016). Plants tolerate moisture stress through mechanisms like maintenance of cell membrane integrity (Leopold et al. 1981), high relative water content (RWC), high chlorophyll stability index (CSI) and osmotic adjustment with proline, glycine betaine. Exposure of capsicum plant to water stress treatment reported to have reduced transpiration rate as an outcome of the increased stomatal conductance. High sensitivity of nitrate reductase and anti - oxidant enzymes to drought stress serves as an excellent tool to assess drought tolerant capacity in crop plants (Correia et al. 2005). However, different cultivars of chilli respond to drought differently. There is a need to select high yielding, moisture tolerant chilli genotypes under rainfed conditions and hence the present investigation was carried out to screen chilli genotypes for drought tolerance.

\section{Materials and Methods}

A pot culture experiment was carried out at glass house facility of Department of Crop Physiology, Tamil Nadu Agricultural University, Coimbatore to screen the chilli genotypes for drought tolerance and to understand various physiological and biochemical mechanisms of drought tolerance. The experimental material for the study comprised of 12 chilli genotypes viz., CA 7, CA 11, CA 41, CA 45, CA 104, CA 116, CA 141, CA 162, CA 174, CA 176, CA 183 and Arka Lohit. Two treatments were imposed viz., $100 \%$ field capacity (FC) and $50 \%$ field capacity (FC), each replicated three times adopting factorial completely randomised block design. capacity weight of pots. Half the volume of water required to maintain $100 \%$ field capacity was poured to pots to maintain $50 \%$ field capacity. Forty five days old seedlings were transplanted to these pots and treatments were imposed 20 days after transplanting to avoid transplanting shock. The pots were maintained at field capacity by weighing reference pots and by adding measured volume of water to each pot at regular intervals. Cultural practices were followed as per the package of practices recommended for Tamil Nadu. All the observations were recorded on physiologically active leaf at the vegetative stage.

The total chlorophyll pigment content in leaves of different genotypes was determined by dimethyl sulphoxide (DMSO) method (Hiscox \& Israelstam 1979). The relative water content (RWC) of leaves of different genotypes was estimated according to Bars \& Weatherly (1962) method by noting the fresh weight, turgid weight and dry weight. Nitrate Reductase activity was estimated in fully expanded functional fresh leaves. The proline content in each leaf was estimated using the method adopted by Bates et al. (1973) and expressed as $\mathrm{mg} \mathrm{g}^{-1}$ fresh weight. Cell Membrane stability index (MSI) was estimated as per the procedure followed by Sairam et al. (1997). Cell Membrane Stability Index was calculated using the following equation and expressed as percentage.

$\operatorname{MSI}(\%)=\left[1-\left(\mathrm{C}_{1} / \mathrm{C}_{2}\right)\right] \times 100$

Where $\mathrm{C}_{1}$ conductivity at $45^{\circ} \mathrm{C}, \mathrm{C}_{2}$ conductivity at $100^{\circ} \mathrm{C}$

The chilli seeds were sown uniformly in well 
The lipid peroxidation level was determined by quantifying the malondialdehyde (MDA) equivalents using 2thiobarbituric acid (TBA) and trichloro acetic acid (Heath \& Packer 1968) and absorbance was measured at 532 and 600nm.The data collected were subjected to statistical analysis in completely randomized block design following the method of Gomez \& Gomez (1984).

\section{Results and Discussion}

\section{Drought and chlorophyll pigment concentration}

The drought significantly reduced the total chlorophyll content of the chilli genotypes. Among the drought imposed plants, the total chlorophyll content varied from $1.42 \mathrm{mg} \mathrm{g}^{-1}$ in CA 7 to $2.82 \mathrm{mg} \mathrm{g}^{-1}$ in CA 183 while under 100 per cent field capacity the highest chlorophyll content of $2.94 \mathrm{mg} \mathrm{g}^{-1}$ was recorded in CA 183 where the decrease in chlorophyll content under drought was found to less (Table 1). The genotypes CA 141 exhibited maximum chlorophyll reduction of $28.10 \%$ in drought compared to control. The decrease in chlorophyll content under drought is considered to be a typical symptom of oxidative stress and may be the result of pigment photo-oxidation and chlorophyll decomposition (Demmig-Adams et al. 1996) or decreased chlorophyll biosynthesis.

Table 1. Effect of drought on total chlorophyll content and relative water content in chilli genotypes

\begin{tabular}{lllllll}
\hline Treatment & \multicolumn{3}{l}{ Total chlorophyll content $\left(\mathrm{mg} \mathrm{g}^{-1}\right)$} & \multicolumn{3}{l}{ Relative water content $(\%)$} \\
Genotypes & Control & Drought & Mean & Control & Drought & Mean \\
\hline CA 7 & 1.73 & 1.42 & 1.57 & 87.27 & 78.50 & 82.92 \\
CA 11 & 2.37 & 2.19 & 2.28 & 76.06 & 64.71 & 70.39 \\
CA 41 & 2.22 & 1.96 & 2.09 & 86.00 & 69.09 & 77.55 \\
CA 45 & 2.01 & 1.79 & 1.90 & 87.67 & 73.38 & 80.53 \\
CA 104 & 1.59 & 1.46 & 1.52 & 90.02 & 64.00 & 77.01 \\
CA 116 & 2.61 & 2.20 & 2.41 & 90.00 & 76.00 & 83.00 \\
CA 141 & 2.31 & 1.66 & 1.99 & 80.00 & 60.00 & 70.00 \\
CA 162 & 1.92 & 1.62 & 1.77 & 86.04 & 77.70 & 81.87 \\
CA 174 & 2.60 & 2.06 & 2.33 & 81.63 & 70.00 & 75.82 \\
CA 176 & 2.74 & 2.07 & 2.40 & 89.74 & 84.37 & 87.06 \\
CA 183 & 2.94 & 2.82 & 2.88 & 89.00 & 84.00 & 86.50 \\
Arka Lohit & 2.75 & 2.56 & 2.65 & 85.48 & 77.78 & 81.63 \\
\hline Mean & 2.38 & 1.98 & 2.15 & 85.74 & 73.30 & 79.32 \\
& G & T & GXT & G & T & GXT \\
SEd & 0.04 & 0.01 & 0.05 & 1.28 & 0.52 & 1.81 \\
CD (p=0.05) & 0.07 & 0.03 & 0.10 & 2.58 & 1.05 & 3.64 \\
\hline
\end{tabular}

G-Genotype, T- Treatment, GXT - Genotype Treatment Interaction

Plant water relations under drought

Relative water content is a measure of plant water status and its maintenance under drought indicates drought tolerance (Altinkut et al. 2001). The maximum decline in relative water content was observed in CA 104 with $28.90 \%$ reduction (Table 1). While the genotypes CA 183 and CA 176 maintained 
high relative water content of $84.37 \%$ and $84.00 \%$ respectively during drought and found to be drought tolerant. Tolerant genotypes are able to sustain high relative water content by maintaining protoplast hydration for a longer span and by reducing water loss through transpiration (Samadia \& Haldhar 2017).

\section{Nitrate Reductase enzyme activity}

Nitrate Reductase enzyme is highly sensitive to water stress and hence used as a biomarker for plant stress. In the present study, limited water availability affected the enzyme activity by $64.70 \%$ and $64.60 \%$ in CA 183 and CA 176 respectively (Fig 1). However, Arka Lohit maintained the same level of Nitrate Reductase activity both under control and drought and these were strongly supported by a study in tomato where the decrease in plant water content due to drought reduced the activity of Nitrate reductase (Umebese et al. 2009). The high sensitivity of Nitrate Reductase to drought was observed in genotypes CA 176 and CA 183 which exhibited a marked reduction in its activity due to decrease in synthesis of Nitrate Reductase protein.

Fig.1. Effect of drought on Nitrate Reductase activity $\left(\mu \mathrm{g} \mathrm{NO} \mathrm{g}^{-1} \mathrm{~h}^{-1}\right)$ in chilli genotypes

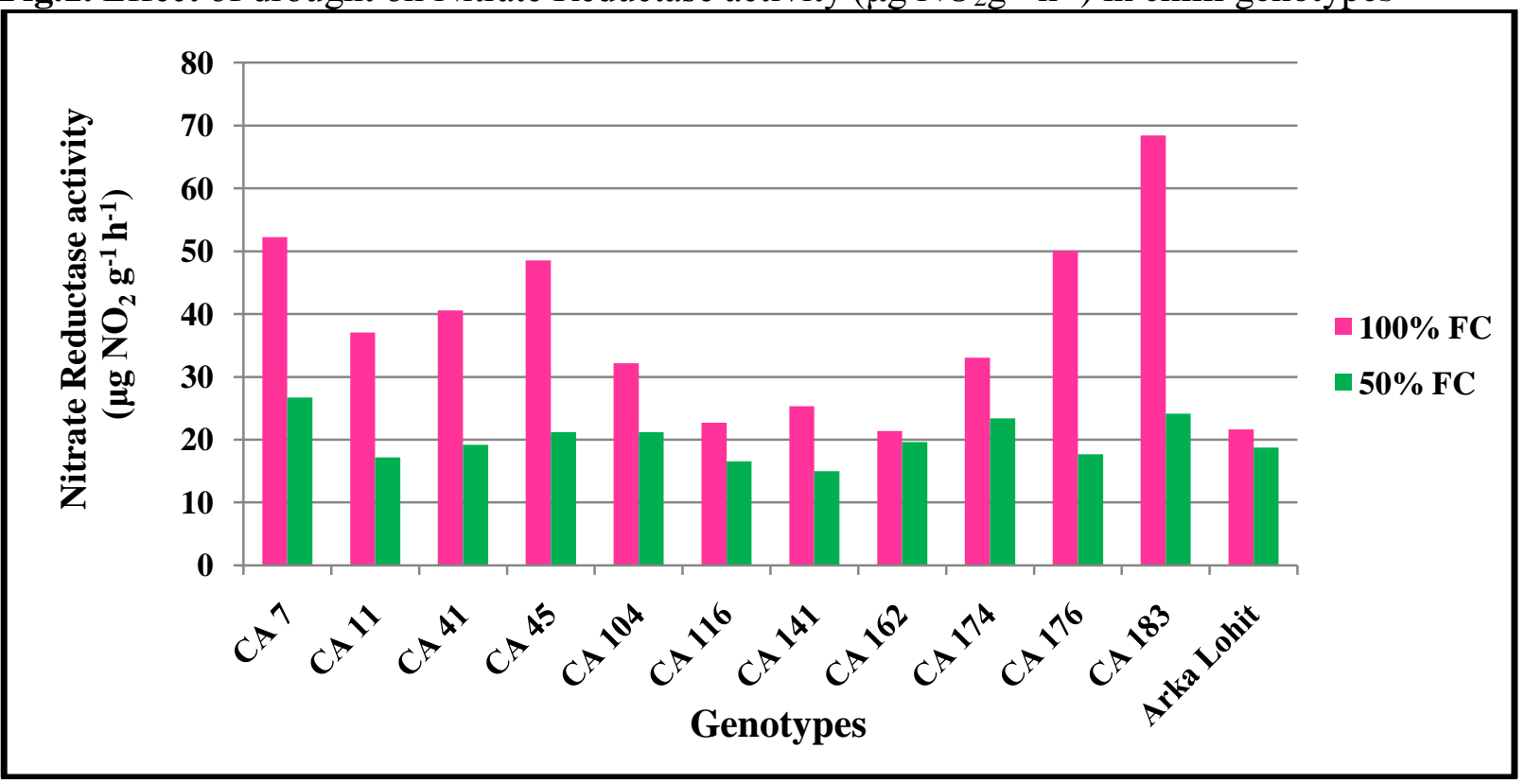

\section{Osmolyte accumulation during drought}

Proline accumulation helps in avoiding detrimental effects of drought and is involved in tolerance mechanisms against oxidative stress. The increase in proline content was observed in all genotypes under drought with the maximum increase of $59.90 \%$ in CA 7 followed by $54.90 \%$ in Arka Lohit while the least increment of $18.10 \%$ was observed in
CA 174 (Fig 2). In CA 174, the proline content was found to be higher both in control (2.04mg $\mathrm{g}^{-1}$ ) and drought (2.49 $\mathrm{mg} \mathrm{g}^{-1}$ ) compared to other genotypes but the drought induced increase in proline content was found to be lower. The results were in agreement with the drought induced proline accumulation in sesame which happened due to the high ROS production and its scavenging 
(Hassanzadeh et al. 2009; Haldhar et al. additional water from environment to 2018). High levels of proline enable the plant withstand the immediate effect of water to maintain low water potential under stress shortage in plants.

and helps in osmoregulation by taking up

Fig.2. Effect of drought on Proline content $\left(\mathrm{mg} \mathrm{g}^{-1}\right)$ in chilli genotypes

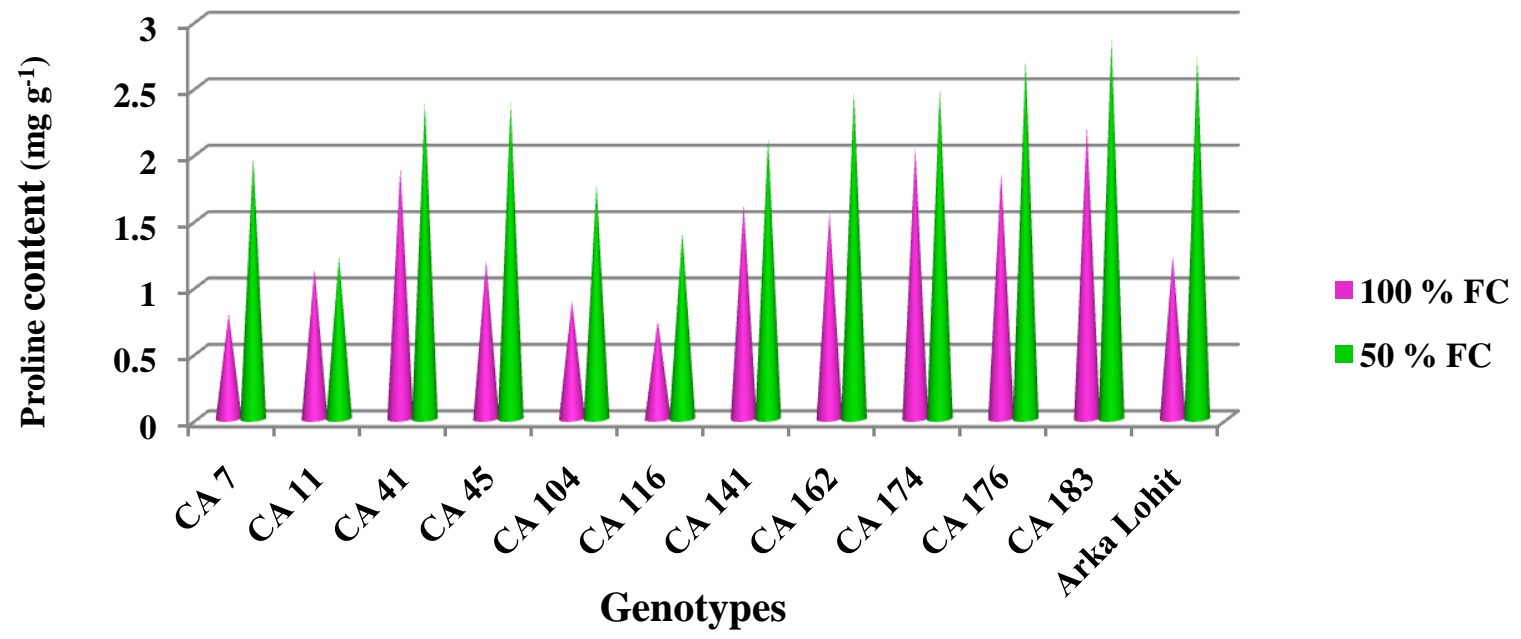

\section{Cell membrane integrity under drought}

Water stress causes decrease in cell membrane stability index (CMSI) and high CMSI during drought indicated better drought tolerance (Gupta et al. 2000). Severe drought induces solute leakage from cells and this directly relates to the cell membrane damage caused by drought. In the study, drought induced reduction of cell membrane stability index was observed in plants. Arka Lohit maintained the supremacy in having the CMSI both under control (81.78\%) and drought (78.69\%) (Table 2). The membrane stability was found to be lower in CA 116 which recorded a reduction of $13 \%$ in drought compared to control. This might be due to the increase in permeability and loss of integrity of cellular membranes (Blokhina 2003). The extent of this abiotic stress can be measured by the solute leakage from the tissues (Chaturvedi et al. 2012). The lipid peroxidation (LPO) helps to determine the level of membrane lipid destruction under stress. During lipid peroxidation, small hydrocarbon fragments such as ketones, malondialdehyde (MDA) etc. are produced when the ROS levels reach beyond threshold level (Moller et al. 2007). LPO decreases the membrane fluidity by increasing the leakiness of the membrane to the substances that usually travel through specific membrane channels. Among the genotypes, CA 174 recorded to have high MDA content $\left(1.02 \mu \mathrm{mol} \mathrm{g}^{-1}\right.$ of fresh weight) under drought (Table 2). The genotypes, CA 176, CA 183 and Arka Lohit recorded to have lower MDA content both under control and drought. The decreased lipid peroxidation indicates higher drought tolerance. From the results it can be concluded 
that the genotype CA 176 showed supremacy over the other genotypes maintaining higher chlorophyll content, relative water content, cell membrane integrity, proline content and lower lipid peroxidation followed by CA 183 in its performance under drought.

Table 2. Effect of drought on cell membrane integrity in chilli genotypes

\begin{tabular}{|c|c|c|c|c|c|c|}
\hline \multirow{2}{*}{$\begin{array}{l}\text { Treatment } \\
\text { Genotypes }\end{array}$} & \multicolumn{3}{|c|}{ Cell membrane stability index (\%) } & \multicolumn{3}{|c|}{$\begin{array}{c}\text { Lipid peroxidation } \\
\left(\mu \mathrm{mol} \mathrm{MDA} \mathrm{g}^{-1} \text { of } \mathrm{FW}\right)\end{array}$} \\
\hline & ontrol & Drought & Mear & Control & Drought & Mean \\
\hline CA 7 & 78.28 & 69.46 & 73.87 & 0.51 & 0.65 & 0.58 \\
\hline CA 11 & .89 & 69. & 74.72 & 0.53 & 0.64 & 0.58 \\
\hline $\mathrm{CA}$ & 74 & 7 & $x$ & 0.52 & 0.56 & 0.54 \\
\hline CA & & & & & & \\
\hline CA & 72 & & 6 & 1 & 0.57 & \\
\hline $\mathrm{CA}$ & 71 & & $x$ & 0.61 & 0.65 & 0 \\
\hline CA 1 & 69 & & c & 0.51 & 0.56 & 0 . \\
\hline & 3 & & $4.8 \zeta$ & 0 & 0.60 & \\
\hline & & & & 0. & $1 .($ & \\
\hline CA & & & 77 & 0 & 0.5 & \\
\hline $\mathrm{CA}$ & 4 & & 78.98 & 0.31 & 0.35 & \\
\hline Arka & 78 & 78 & 8 & 0.21 & 0.39 & \\
\hline \multirow[t]{2}{*}{ Mean } & & & & 0.47 & 0.60 & \\
\hline & & $\mathrm{T}$ & GXT & G & & GXT \\
\hline SEd & 1. & 0.4 & 1.46 & 0.01 & 0.004 & 0.01 \\
\hline $\mathrm{CD}(\mathrm{p}=0.05)$ & 2.07 & 0.84 & NS & 0.02 & 0.007 & 0.02 \\
\hline \multirow{2}{*}{\multicolumn{4}{|c|}{$\begin{array}{l}\text { Acknowledgement } \\
\text { We thank Dr. Irene P. Vethamoni, } \\
\text { Dean, RVS Padmavati College of } \\
\text { Horticulture, Sempatti and Dr.T. Sivakumar, } \\
\text { Associate Professor, Department of Crop } \\
\text { Physiology, Tamil Nadu Agricultural } \\
\text { University, Coimbatore for their critical } \\
\text { suggestions and valuable remarks. }\end{array}$}} & $\begin{array}{l}\text { Agricultura } \\
65(2): 121-1\end{array}$ & Water & \\
\hline & & & & $\begin{array}{r}\text { Barrs } \mathrm{H} \& \mathrm{~W} \\
\text { examination } \\
\text { technique fo } \\
\text { leaves. Aus } \\
\text { Sciences, } 15\end{array}$ & $\begin{array}{l}\text { therley } \mathrm{F} \\
\text { of the } \mathrm{r} \\
\text { estimating } \\
\text { lian Jour } \\
\text { 3): } 413-42\end{array}$ & $\begin{array}{l}\text { 1962. A re- } \\
\text { ative turgidity } \\
\text { vater deficits in } \\
\text { of Biological }\end{array}$ \\
\hline \multirow{2}{*}{\multicolumn{4}{|c|}{$\begin{array}{l}\text { References } \\
\text { Altinkut A, Kazan K, Ipekci Z \& Gozukirmizi } \\
\text { N. 2001. Tolerance to paraquat is } \\
\text { correlated with the traits associated with } \\
\text { water stress tolerance in segregating } F_{2} \\
\text { populations of barley and wheat. } \\
\text { Euphytica, } 121(1): 81 .\end{array}$}} & Bates L, Waldre & $\mathrm{R} \& \mathrm{Te}$ & I. 1973. Rapi \\
\hline & & & & $\begin{array}{l}\text { determinatic } \\
\text { stress studie } \\
207 . \\
\text { Blokhina O. 20 } \\
\text { Damage anc } \\
\text { a Review. A }\end{array}$ & $\begin{array}{l}\text { Antiox } \\
\text { Dxygen I } \\
\text { zals of } B\end{array}$ & $\begin{array}{l}\text { line for water- } \\
\text { oil, 39(1): 205- } \\
\text { ants, Oxidative } \\
\text { rivation Stress: } \\
n y, 91(2): 179-\end{array}$ \\
\hline \multicolumn{4}{|c|}{$\begin{array}{l}\text { Antony E \& Singandhupe R. 2004. Impact of } \\
\text { drip and surface irrigation on growth, } \\
\text { yield and WUE of capsicum. }\end{array}$} & $\begin{array}{l}194 . \\
\text { Chaturvedi AK, } \\
\text { 2012. Clo } \\
\text { type } 2 \mathrm{~m}\end{array}$ & athione & $\begin{array}{l}\text { ari V \& Jha B. } \\
\text { ript analysis of } \\
\text { sene (SbMT-2) }\end{array}$ \\
\hline
\end{tabular}


from extreme halophyte Salicornia brachiata and its heterologous expression in E. coli. Gene, 499(2): 280287.

Correia MJ, Fonseca F, Azedo-Silva J, Dias C, David M, Barrote I\&Osório J. 2005. Effects of water deficit on the activity of nitrate reductase and content of sugars, nitrate and free amino acids in the leaves and roots of sunflower and white lupin plants growing under two nutrient supply regimes. Physiologia Plantarum, 124(1): 61-70.

Demmig-Adams B, Adams IW, Barker DH, Logan BA, Bowling DR \& Verhoeven AS. 1996. Using chlorophyll fluorescence to assess the fraction of absorbed light allocated to thermal dissipation of excess excitation. Physiologia Plantarum,98(2):253-264.

Gladden LA, Wang YM, Hsieh CH \& Tsou I. 2012. Using deficit irrigation approach for evaluating the effects of water restriction on field grown tomato. African Journal of Agricultural Research, 7(14):2083-2095.

GomezKA \& Gomez AA. 1984. Statistical procedures for agricultural research.New York, Wiley Inter-Science Publications. p. 253-259.

Gupta N, Gupta S \& Kumar A. 2000. Exogenous cytokinin application increases cell membrane and chlorophyll stability in wheat (Triticum aestivum L.). Cereal Research Communications, p. 287-291.

Haldhar SM, Berwal MK, Samadia DK, Kumar R, Gora JS \& Choudhary S. 2018. Biochemical basis of plant-insect interaction in arid horticulture crops: a scientific review. Journal of Agriculture and Ecology, 6: 1-16.

Hassanzadeh M, Ebadi A, Panahyan-E-Kivi M, Eshghi A, Jamaati-E-Somarin S, Saeidi M\& Zabihi-E-Mahmoodabad, R. 2009. Evaluation of drought stress on relative water content and chlorophyll content of sesame (Sesamum indicum L.) genotypes at early flowering stage. Research Journal of Environmental Sciences, 3(3):345-350.

Hazrati S, Tahmasebi-Sarvestani Z, ModarresSanavy SM, Mokhtassi-Bidgoli A \& Nicola S. 2016. Effects of water stress and light intensity on chlorophyll fluorescence parameters and pigments of Aloe vera L.Plant Physiology and Biochemistry, 106:141-148.

Heath RL \& Packer L. 1968. Photoperoxidation in isolated chloroplasts: II. Role of electron transfer. Archives of Biochemistry and Biophysics, 125(3) : 850-857.

Hiscox JT\& Israelstam G. 1979. A method for the extraction of chlorophyll from leaf tissue without maceration. Canadian Journal of Botany, 57(12): 1332-1334.

Leopold AC, Musgrave ME \& Williams KM. 1981. Solute leakage resulting from leaf desiccation. Plant Physiology, 68(6): 1222-1225.

Moller IM, Jensen PE \&Hansson A. 2007. Oxidative modifications to cellular components in plants. Annual Review of Plant Biology, 58: 459-481.

Sairam R, Deshmukh P \& Shukla D. 1997. Tolerance of drought and temperature 
stress in relation to increased antioxidant enzyme activity in wheat.Journal of Agronomy and Crop Science, 178(3):171-178.

Samadia DK \& Haldhar SM. 2017. Breeding strategies and scope of improvement in arid zone fruit crop-plants under abiotic stressed agro-climate: an analysis. Journal of Agriculture and Ecology, 4: 1-13.

Singh SK \& Raja Reddy K. 2011. Regulation of photosynthesis, fluorescence, stomatal conductance and water-use efficiency of cowpea (Vigna unguiculata L.) under drought. Journal of Photochemistry and Photobiology, 105(1): 40-50.
Sivakumar R, Durga Devi D, Chandrasekar CN, Santhi R \&Vijayakumar RM. 2014. Impact of drought on gas exchange and physiological parameters and yield in contrasting genotypes of tomato (Solanum lycopersicum). Indian Journal of Plant Physiology, 19(1): 1-7.

Umebese $\mathrm{C}$, Olatimilehin $\mathrm{T}$ \&Ogunsusi $\mathrm{T}$. 2009. Salicylic acid protects nitrate reductase activity, growth and proline in amaranth and tomato plants during water deficit.American Journal of Agricultural and Biological Sciences, 4(3) : 224-229. 